\title{
INVESTIGATING QASSIM UNIVERSITY EFL INTENSIVE COURSE PROGRAM INSTRUCTORS' PERSPECTIVES TOWARDS UTILIZING BLACKBOARD COLLABORATE AS AN EMERGENCY REMOTE TEACHING TOOL DURING THE 2020-2021 COVID-19 PANDEMIC
}

\author{
Mustafa Mohammed Sadek Elsayed \\ Dr. Department of English Language and Translation, College of Science and Arts in Unaizah, \\ Qassim University, Saudi Arabia, mustafasadek2000@gmail.com
}

\begin{abstract}
Purpose: The outbreak of COVID-19 pandemic caused a sudden shift to online teaching and learning which resulted in confusion for higher education institutions not only in Saudi Arabia, but worldwide as well. Due to the broad availability of technology infrastructure in Saudi higher education institutions, Blackboard Collaborate is widely used in most Saudi universities. As positive perspectives were found to play an important impact in the adoption of new technology in earlier research, this paper aims to investigate Qassim University EFL Intensive Course Program (ICP) instructors' perspectives towards utilizing the Blackboard Collaborate as an emergency remote teaching tool during COVID-19 pandemic.

Design/methodology/approach: To collect data from the participants, the study employed a qualitative research method, namely, semi-structured interviews with 15 ICP EFL instructors. The interviews were face to face and included predetermined questions that focused on the pros and cons of utilizing Blackboard Collaborate as a remote teaching tool during Covid-19 pandemic.

Findings: The study revealed the pros and cons of using the Blackboard Collaborate as a remote teaching tool during COVID-19 pandemic as perceived by ICP EFL instructors. While the pros included novel teaching methods in Blackboard Collaborate, offering interactive lessons via using Blackboard Collaborate, and a great deal of motivation resulted from using Blackboard Collaborate, the cons comprised ICP EFL instructors' lack of competency in using Blackboard Collaborate, students' lack of competency in using Blackboard Collaborate, and technical problems.

Originality/value: Most literature published on using Blackboard Collaborate in the Saudi higher education context focused on using it in teaching EFL advanced learners with prior experience with Blackboard Collaborate. To my knowledge, this is the first paper to investigate the participants' perspectives towards using the Blackboard Collaborate in teaching secondary school leavers without prior experience with Blackboard Collaborate like ICP EFL students.
\end{abstract}

Keywords: EFL Intensive Course Program, instructors' perspectives, Blackboard Collaborate, COVID-19 pandemic

\section{INTRODUCTION AND CONTEXT OF THE RESEARCH}

Many countries all over the world had to take preventive measures because of the outbreak of the COVID-19 pandemic. These measures have resulted in numerous changes at all levels, social interaction, and 
organization, including the education sector (Murphy, 2020). In a short time, face-to-face traditional classes were ceased, and emergency online learning came to be the ideal, and in many cases the only, available substitute. Although this procedure has demonstrated to be one of the most highly successful nonpharmaceutical interventions imposed by governments in controlling the spread of the disease (Flaxman, 2020; Moosa, 2020). Due to the disrupted circumstances associated with the sudden school closure, all parties involved in the educational process, government officials, educational institutions, educators, parents and students were put under tremendous pressure to ensure the continuity of learning process. Given the urgency of the COVID-19 pandemic outbreak, as well as the complexity and ambiguity of the scenario of facing crises resulted from it, it is logical that all parties involved in the educational process would be tolerant and accepting of a less-than-perfect performance, especially during the pandemic's first wave. Still, given the virus and its variants thus far uncontrollable spread, it will be impossible to estimate how long these disruptions will last. What is predictable is that education, like all other sectors of life, will never be the same, and that the crisis will have a long-term impact on learning innovation and digitization (Hodges et al., 2020). As a result, flexible and mature long-term plans to address the effects of the current crisis, as well as other potential disruptions to education, must be considered. Equally essential, these plans must take into account instructors' and learners' attitudes, suggestions, and concerns based on their experiences during the first wave of crises (Hodges et al., 2020).

To ensure learning continuity during the suspension period, the Saudi Ministry of Education called for virtual classes and distant education on March 8, 2020 (Desk, 2020). As a result, numerous e-learning platforms have been used, including the Blackboard Collaborate, which is one of the most widely used by higher education institutions in Saudi Arabia. However, as the COVID-19 pandemic spreads all over the world, these online educational platforms are being used to substitute face-to-face classes in order to protect communities, students, instructors, and professors from the pandemic while also ensuring the continuation of education (Sobaih et al., 2020). The COVID-19 pandemic has accelerated online learning in the education setting after a sudden closure of schools, colleges and universities throughout the world. It expedited the adoption of online learning as a medium of instruction. In order to guarantee continuity of quality education during COVID-19 pandemic online delivery of courses has been initiated immediately at all academic levels of higher education institutions. All public universities in Saudi Arabia have adopted Blackboard as their major learning management system (Al Shammari, 2021).

Qassim University has been one of the leading higher education institutions in the Kingdom of Saudi Arabia to adopt new and improved online learning innovations. Under its umbrella is the College of Science and Arts in Unaizah which is the focus of this study which aims to investigate the perspectives of EFL ICP instructors towards utilizing Blackboard Collaborate as a remote teaching tool during the COVID-19 pandemic. This will define which factors have an effect on the attitudes of ICP instructors toward adopting online teaching. It is worth noting that most ICP instructors at the College of Science and Arts in Unaizah were anxious and uncertain when they were suddenly compelled to use online platforms for their teaching sessions instead of traditional face to face lecturing. This has been the first real glitch they have encountered in their teaching career, however, even the most traditional instructors have adapted to online teaching for their lectures! This adaptation has become the urgent need of the hour while dealing with barriers to teaching and learning caused by Covid-19 pandemic. The importance of online education has been illustrated by this rapid shift towards online learning and is highly likely to become more incorporated into routine education and to be considered central in the new academic world. However, there is a gap in the literature in the Saudi higher education context toward studying the attitudes that ICP instructors exert toward implementing online teaching in general and using Blackboard Collaborate in particular.

\section{LITERATURE REVIEW}

\subsection{Using Blackboard in Higher Education Context Prior to COVID-19 Pandemic}

The investigation of participants' perspectives regarding emergency online learning, the key challenges they face, and ideas for overcoming them is among the many significant topics addressed by this flow of research. Numerous studies have emphasized the importance of integrating the Blackboard into the teaching system. Within this context, Alokluk (2018) pointed out that utilizing Blackboard revolutionized the traditional system of the learning/teaching process and resulted in effective education. Many universities have started using the Blackboard as part of their Learning Management System because of its easiness, universality, and accessibility (Mohsen \& Shafeeq, 2014). During the last few years, the Blackboard has rapidly become popular among colleges and universities students and instructors worldwide (Al-Meajel \& Sharadgah, 2018). In a similar vein, Blackboard was defined as a software package that teachers can use to create high-quality online courses (Choy et al., 2005). Accordingly, the Blackboard system is intended to support teaching and 
learning: promoting not only teacher-learner interaction but also interaction among students (Al-Naibi et al., 2015). The Blackboard system is also supplied with features and tools that enable the students to be involved in learning outside the classroom anywhere and anytime (D'Silva \& Reeder, 2005).

Previous studies discovered that the employment of technological applications can be impacted by the users' views and perspectives towards the systems and their use. Consequently, the users' readiness and acceptance to use the system are vital for successful implementation (Almarabeh, 2014). According to AlDrees et al. (2015), the "effective utilization of the Blackboard learning system mainly depends on students and faculty members' background, readiness and acceptance of such system" (p.17). Sheerah (2020) highlighted the issue that practitioners' use of modern technology is not only a tool for enhancing the learning/teaching process, but also for improving classroom activities and ensuring better delivery of the curriculum. Additionally, Banditvilai (2016) examined the effectiveness of blended learning in self-directed language learning and found that it has a positive advantage since the study's findings demonstrated that online materials are beneficial to improving language skills and autonomous learning. Similarly, in a case study, Nyabawa 2016, examined the effectiveness of using Blackboard. The findings of this study revealed that Blackboard had a positive impact on students' performance. In the same token, Uziak et al. (2018) found that students felt comfortable when using Blackboard; their performance developed, and communication with instructors was significantly improved.

There are some studies related to using the Blackboard system in the Saudi higher education context. For example, in their research at Al Jouf University in Saudi Arabia, Pusuluri et al. (2017) found that students are split on whether Blackboard provides a vibrant and stimulating environment. The findings of their study, however, suggested that the Blackboard could be a useful medium for providing instructions motivations. In the same way, Hamad (2017), investigated the advantages and disadvantages of utilizing Blackboard for Blended Learning and its impact on students learning outcomes. He concluded that there are more pros than cons, and students are pleased with using Blackboard. According to Al-qahtani (2019), students' attitudes and perspectives towards using virtual classes are both positively and negatively influenced. The study's findings also indicated some pros, such as ease of use, as well as drawbacks, such as the lack of a sensation of being in a real class.

In a case study of students at University of Bisha in Saudi Arabia, Ja'ashan (2015), found out that students' perceptions and attitudes toward Blended Learning are positive because it aids in improving their learning, motivating teacher-student interaction, and giving students enough time to complete their tasks. Though, the study also showed negative impressions such as easy cheating, a waste of time, and social isolation. In a recent study, Ja'ashan (2020) stated that students have a high positive attitude towards Blackboard and are aware of the benefits of using E-learning. Al-Maqtri (2014), on the other hand, carried out a case study at King Khalid University in Saudi Arabia. According to the findings, teachers believed that E-learning via Blackboard is effective; however students (both male and female) do not consider E-learning via Blackboard effective. In a similar way, Al Zumor et al. (2013) investigated the effectiveness of utilizing Blackboard in blended learning modules. According to the results of the study, the majorities of participants (160 male EFL undergraduates) were dissatisfied in general with the blended learning courses and thought that Blended learning was less effective than face-to-face learning. When Al Meajel \& Sharadgah (2018) investigated the challenges and the difficulties for utilizing the Blackboard system in the teaching/learning process, they concluded that both technological barriers and institutional barriers were the most highly identified barriers. While the student barriers category came in the third level, the faculty barriers category ranked at the lower end. In terms of using the Blackboard system at Qassim University in general and in the College of Science and Arts in Unaizah in particular before the spread of COVID-19, it could be mentioned that it was mainly used for posting lectures, uploading study materials, projects, assignments, tests and quizzes and was not used as the only medium of instruction.

\subsection{Using Blackboard in Higher Education Context during COVID-19 Pandemic}

"Along with their students, faculty were "thrown into the deep end of the pool for digital learning and asked to swim.....Some will sink, some will crawl to the edge of the pool and climb out and they'll never go back in the pool ever again. But many will figure out what to do and how to kick and how to stay afloat."

Will the Coronavirus Forever Alter the College Experience?

\section{New York Times}

April 23, 2020

Following the outbreak of the COVID-19 epidemic, a debate erupted about whether the shift to online 
education would be a boon or bane. Experts had a debate if the pandemic would encourage students and faculty to embrace online learning or if it would turn a generation away from it (Lederman, 2020). In the aftermath of the COVID-19 outbreak, many countries all over the world ceased in-person classes and switched instruction to various sorts of virtual environments. This huge and obligatory shift has been associated with a universal flow of research production on various features of the emergency distant and online learning forced by the COVID-19 pandemic. Synchronous platforms like Zoom and Blackboard are currently used in the Saudi higher education context. Nowadays all Saudi universities use Blackboard widely as one of their e-learning platforms. The Blackboard, among other online learning systems utilized during the COVID-19 pandemic, has been the theme of numerous investigations and research publications recently. For example, Chen et al. (2020) investigated the Open University Australia students' perceptions about using Blackboard in online learning during the COVID-19 pandemic. The findings of the study indicated that students' perspectives about the Blackboard as a tool for real-time engagement, knowledge sharing, and feedback exchange were positive. In the Saudi higher education context is the study carried out by Khafaga (2021) to examine how modern technologies contribute to the teaching/learning process in Saudi universities. According to the findings of this study, Blackboard was found to be beneficial for both synchronous and asynchronous learning. In a similar study, Elsamanoudy et al. (2020) stated that the Blackboard served as an effective substitute for traditional classrooms during the COVID-19 lockdown, with students being able to join sessions at any time, from any location, using any device. According to Almelhi (2021), students had positive attitudes towards using the Backboard due to its accessibility, quality and convenient use. On the contrary, Almekhlafy (2020) carried out a study to investigate students' perceptions towards the online learning through Blackboard. The study revealed the students' negative perceptions towards using the Blackboard.

After the outbreak of COVID-19 pandemic and due to the quarantine, the Blackboard Collaborate has been broadly used as the only medium of instruction by all faculty members of Qassim University. That is, it has been shifted from a supplementary instructional tool to a primary one that can be used for virtual classes, discussion, blogs, electronic exams, assignments, course messages, and other online synchronous and asynchronous activities in addition to uploading and downloading lectures, course syllabi, study materials, assignments, homework, and quizzes. The COVID-19 pandemic has strengthened the significance of technology and virtual learning in education. Despite the fact that online learning offered both teachers and learners various benefits, the unexpected shift to a virtual environment due to the pandemic has resulted in different perceptions in using the Blackboard Collaborate as an emergency remote teaching tool. Therefore, the purpose of this research is to understand the perceptions and concerns of Qassim University EFL ICP instructors towards using Blackboard Collaborate as an emergency remote teaching tool during COVID-19 pandemic.

\section{RESEARCH QUESTIONS}

The purpose of this study is to identify the pros and cons of using Blackboard Collaborate as a remote teaching tool during Covid-19 pandemic as perceived by ICP instructors. More specifically, the study seeks to respond to the following questions in relation to ICP instructors' experience with using Blackboard Collaborate as a remote teaching tool during the first few weeks of the shift from face-to-face learning to online learning in the context of the COVID-19 pandemic:

RQ1: What are the pros of using Blackboard Collaborate as a remote teaching tool during Covid-19 pandemic as perceived by ICP instructors?

RQ2: What are the cons of using Blackboard Collaborate as a remote teaching tool during Covid-19 pandemic as perceived by ICP instructors?

\section{OBJECTIVES OF THE RESEARCH}

This paper aims to meet two research objectives:

1. To explore the pros of using Blackboard Collaborate as a remote teaching tool during Covid-19 pandemic as perceived by ICP instructors.

2. To explore the cons of using Blackboard Collaborate as a remote teaching tool during Covid-19 pandemic as perceived by ICP instructors.

\section{SIGNIFICANCE OF THE RESEARCH}

This paper is in support of the adoption of online teaching in Qassim University and specifically at College of Science and Arts in Unaizah. To my knowledge, it is the first research to explore the perceptions of ICP 
instructors at Qassim University towards the adoption of Blackboard Collaborate as a remote teaching tool in the Saudi higher education setting. Exploring instructors' perceptions towards adopting online teaching is an essential element to define factors that are inhibiting the adoption of online teaching. This could help in predicting how the online educational system will change across Saudi universities in the near future.

Basically, new online teaching methods should not be employed without completely understanding their effect on the instructors' teaching. A more successful and effective transition from traditional instruction to online teaching can be assured by a thorough investigation of the issues that improve or challenge the expertise of the instructors. This paper contributes to the knowledge of online teaching theoretically and practically.

Theoretically, changing the traditional mode of delivering education to online one in Saudi Arabia due to the COVID-19 Pandemic, particularly in a higher education institution, like Qassim University, is still in its very early stages. This research will assist in providing insight into the perceptions of instructors towards delivering their courses in online teaching mode.

According to Brooks (2015), "faculty members have a lot of experience teaching with technology but would like more evidence of its efficacy and more training on how to better incorporate technology into their classrooms". Practically, this research can help higher education institutions identify areas where their faculty members need professional development and training on how to deal with electronic platforms and develop their knowledge about the different platforms and systems used in online teaching.

\section{RESEARCH DESIGN}

The study was conducted in the first semester of 2021, after ICP instructors completed teaching their online courses. This study applied a qualitative method in which focus group interviews were utilized to explore the pros and cons of using Blackboard Collaborate as a remote teaching tool during Covid-19 Pandemic at College of Science and Arts in Unaizah, Qassim University, Saudi Arabia. Focus group interviews, according to Jackson (1998), are flexible and relatively easy to conduct. A wide range of themes can be attained via focus group interviews as comments from one participant may generate responses from others (McLafferty, 2004; Jackson, 1998).

\subsection{Participants}

The purposive sample of this study included 15 ICP instructors at the English language Department in College of Science and Arts in Unaizah, Qssim University, Saudi Arabia. In general, 15 participants are sufficient for focus group interviews (Goss \& Leinbach, 1996). The participants' ages range from 35 to 45. They have been teaching English as a Foreign Language for more than 7 years. Due to the outbreak of COVID-19 Pandemic and the shift from traditional teaching to online teaching, the participants have been implementing the Blackboard as a teaching tool for two academic semesters. Most of them had received some training sessions in Blackboard Collaboarte by Qassim University Deanship of E-Learning and Distance Learning. The data was collected by the author of this study who is the coordinator of the ICP and the main tutor of ICP students. Based on the ICP instructors' interest to participate in the study, the 15 participants were interviewed to express their perceptions verbally. All participants participated voluntarily, and the college's institutional review board approved all research procedures.

\subsection{Instrumentation}

According to Sewell (2008), semi-structured interviews reduce bias when different responses are compared. Similarly, Creswell (2012) explained that semi-structured interviews generate information that might not be expected by the researchers. To collect data from the participants, semi-structured interviews were used. The interviews included predetermined questions that focus on the pros and cons of utilizing Blackboard Collaborate as a remote teaching tool during Covid-19 pandemic. The interviews were carried out face-toface with the 15 participants. According to O'Reilly (2005), interviews are considered powerful tools for information gathering as participants are allowed to express their views freely on a specific topic (O'Reilly, 2005). Fifteen ICP instructors were offered the opportunity to express their opinions, perceptions and attitudes frankly and orally. The semi-structured interview questions concentrated on instructors' perceptions of utilizing Blackboard Collaborate as teaching tool during COVID-19 pandemic. Participants expressed their perspectives on the pros and cons of utilizing Blackboard Collaborate as a teaching tool during the pandemic, its contributions to developing students' language skills, and practical difficulties to effective Blackboard Collaborate integration in learning English language courses during the COVID-19 Pandemic. 


\section{RESULTS OF THE RESEARCH, ANALYSIS AND DISCUSSION}

The interview data were analyzed qualitatively using grounded theory (Corbin and Strauss 2015), and based on the constant comparative method (Glaser \& Strauss, 1967; Corbin and Strauss 1990). Instead of grouping data based on an existing theory or a priori classifications, this established methodology for coding qualitative data encourages analysts to create or adapt concepts from data. The interview data were initially analyzed as a single pool. To categorize participants' responses, all data were reviewed and reread again. Participants' similarities, differences, and complementarities were examined between and within groups. The constant comparative approach was used to code, conceptualize, and categorize any words or sentences relating to the EFL faculty members' perspectives towards the pros and cons of utilizing Blackboard Collaborate as a teaching tool during the COVID-19 pandemic. There were two stages of analysis in order for obtaining trustworthiness. The first stage included abstracting the preliminary categories; then, comparing notes and agreeing on list of categories. The second stage included bringing examples from the data to support the categories, refining the categories and supporting their final structure.

\section{Research Question 1: What are the pros of using Blackboard Collaborate as a remote teaching tool during COVID-19 pandemic as perceived by ICP instructors?}

From the perspectives of ICP instructors, three categories emerged from the collected data regarding the pros of using Blackboard Collaborate as a remote teaching tool during the Covid-19 pandemic: novel teaching methods in Blackboard Collaborate, using Blackboard Collaborate as a remote teaching tool offers interactive lessons, and using Blackboard Collaborate as a remote teaching tool has a great deal of motivation.

In regard with the novel teaching methods in Blackboard Collaborate, the ICP instructors frequently remarked during the interviews that Blackboard Collaborate has come up with several novel teaching methods which aid in making EFL ICP education more engaging. Using Blackboard Collaborate in teaching English language skills allows ICP students to receive instant feedback from their instructors. Additionally, using online materials (audio/video/text) helps in making the online education experience much livelier and richer. Moreover, online exercises, practice tests and quizzes help ICP instructors to check, monitor and track their students' progress of language skills acquisition. According to some ICP instructors, language skills were also boosted by using Blackboard Collaborate as a remote teaching tool. One instructor stated that using Blackboard Collaborate was a good venue for his students to practice writing while receiving feedback from their instructor.

Using Blackboard Collaborate as a remote teaching tool offers interactive lessons. Almost all participants agreed that using Blackboard Collaborate as a remote teaching tool facilitates interactive lessons by allowing students to communicate with their instructors at any time and from anywhere. One of the participants believed that using Blackboard Collaborate as a remote teaching tool could create instructor-student relationship through online assignments.

Using Blackboard Collaborate as a remote teaching tool has a great deal of motivation. Instructors frequently supposed that Blackboard Collaborate's motivational aspect was quite strong. Its interactive aspects such as discussion sessions and chatting enabled a great deal of peer learning. One of the participants claimed that because there were no time limits for students to access the information on Blackboard Collaborate, it aided them in making up for missed classes. Other participants believed that the fear-free atmosphere, in comparison with face to face traditional classrooms, was additional motivator for students to participate. As one of the participants pointed out, offering autonomy is one of the main features in justifying using Blackboard Collaborate as a remote teaching tool in the English language teaching-learning environment. Another participant commented, "By using Blackboard Collaborate as a remote teaching tool there will not be any traditional face to face classroom monotony." Another participant added that Blackboard Collaborate was an urgent alternative for traditional face to face classrooms.

\section{Research Question 2: What are the cons of using Blackboard Collaborate as a remote teaching tool during COVID-19 pandemic as perceived by ICP instructors?}

Despite the many pros of using Blackboard Collaborate as a remote teaching too during COVID-19 pandemic mentioned by the majority of ICP instructors, they do point out various cons that prevent effective Blackboard Collaborate integration in the EFL education context. These cons can be classified into three: ICP instructors' lack of competency in using Blackboard Collaborate, students' lack of competency in using Blackboard Collaborate, and Technical Problems.

In regard to the ICP instructors' lack of competency in using Blackboard Collaborate, some ICP instructors 
who were new to using Blackboard Collaborate, as stated by one of the participants, could find it challenging to shift from a traditional face-to-face instruction to online learning setting. This challenge stems in part from their inexperience with using Blackboard Collaborate. The lack of technical staff added to the challenge, as many ICP instructors pointed out.

Pertaining to the students' lack of competency in using Blackboard Collaborate, some ICP instructors expressed their concern about the low student response to the Blackboard Collaborate assignments. The causes for this differ. "Some of the ICP students are not well-prepared or properly informed of how to use the Blackboard Collaborate," one of the instructors remarked. This is due to the fact that not all students, particularly those from remote rural areas, have access to the Internet. Another challenge faced by ICP new coming students is the language barrier as Blackboard Collaborate instructions are all written in English and students without proper training may find it difficult to deal with it. One of the instructors, amusingly, added that some students were attracted to other internet activities such as watching videos on YouTube, Instagram and other social networking such as twitter and Facebook.

Technical Problems is another cons mentioned by some of the ICP instructors. According to some instructors, Blackboard Collaborate wasn't always reliable. One of the instructors pointed out that the complexity of some applications like Blackboard Collaborate may deter some students from using them. Despite the fact that most ICP instructors emphasized the pros of using Blackboard Collaborate, others noted that it may not be valid to be applied to teaching some language skills that require face to face instruction.

\section{IMPLICATION AND CONCLUSION}

According to the findings, ICP instructors have positive perspectives towards the use of the Blackboard Collaborate in ICP English language instruction. This indicates that most ICP instructors have positive perspectives towards integrating Blackboard Collaborate in language teaching. As earlier studies, (Albion \& Ertmer, 2002; Ertmer, Gopalakrishnan, \& Rosse, 2001), have shown, positive perspectives play an important impact in the adoption of new technology in teaching and learning process. Most ICP instructors see Blackboard Collaborate as an effective teaching platform that aids in the improvement of the instructor student interaction in the ICP course and aids in the successful teaching of all English language skills. Instructors' technological and pedagogical understandings, as evidenced by earlier findings (Comas-Quinn, 2011; Hauck \& Stickler, 2006), aid in the successful implementation of web-based teaching-learning activities. Because the majority of the participants said they could simply utilize the Blackboard Collaborate, the easiness of using Blackboard Collaborate by ICP instructors as a remote teaching tool has been proved. Though some ICP instructors have expressed some reservations about the practical aspects of utilizing Blackboard Collaborate, the majority of instructors have rejected the notions that it is difficult to use or that it lacks adaptability or customization. Furthermore, the fact that the majority of ICP instructors agree that Blackboard Collaborate encourages interaction between instructors and their students by allowing students to communicate with their instructors at any time and from anywhere is a positive aspect. Hence, through the participants' responses to the research questions proposed for this research, it could be concluded that the participants find that using Blackboard Collaborate as a remote teaching tool is effective in enhancing the teaching learning process.

\section{LIMITATIONS OF THE RESEARCH}

During the COVID-19 pandemic, this research was conducted while the ICP instructors were already undergoing instruction for the different aspects of online learning. Because this qualitative study is limited in scope, it is necessary to conduct similar studies in different EFL higher education institutions and compare the results for match and mismatch of instructors' perspectives towards using Blackboard Collaborate as a remote teaching tool. In addition, separate research should be carried out to explore the attitudes of students towards the adoption of using Blackboard Collaborate as a remote online learning tool, along with assessing how the online courses should be performed and the level of satisfaction of the faculty.

\section{REFERENCE LIST}

Albion, P. R., \& Ertmer, P. A. (2002). Beyond the foundations: The role of vision and belief in teachers' preparation for integration of technology. TechTrends, 46(5), 34-38. 
Proceedings of INTCESS 2022- 9th International Conference on Education \& Education of Social Sciences 17-18 January 2022- Online Conference

Al-Drees, A., Khalil, M. S., Meo, S. A., \& Abdulghani, H. M. (2015). Utilization of blackboard among undergraduate medical students: Where we are from the reality? Journal of Taibah University Medical Sciences, 10(1). https://doi.org/10.1016/j.jtumed.2014.07.002

Al-Maqtri, M. A. T. (2014). How Effective is E-learning in Teaching English? : A Case Study. . Journal of Education and Human Development. http://jehdnet.com/vol-3-no-2-june-2014-abstract-39-jehd

Almarabeh, T. (2014). Students' Perceptions of E-learning at the University of Jordan. International Journal of Emerging Technologies in Learning (IJET), 9(3). https://doi.org/10.3991/ijet.v9i3.3347

Al Meajel, T.M. and Sharadgah, T.A. (2018), "Barriers to using the blackboard system in teaching and learning: faculty perceptions", Technology, Knowledge and Learning, Vol. 23 No. 2, pp. 351-366, available at: www.researchgate.net/publication/312136352

Almekhlafy, S. S. A. (2020). Online learning of English language courses via blackboard at Saudi universities in the era of COVID-19: perception and use. PSU Research Review, 5(1). https://doi.org/10.1108/PRR-08-2020-0026

Almelhi, A. M. (2021). The Role of the Blackboard LMS in EFL Course Delivery During the COVID-19 Pandemic: Investigating Attitudes and Perceptions of Faculty and Students. International Journal of English Linguistics, 11(2). https://doi.org/10.5539/ijel.v11n2p46

Al-Naibi, S. A., Madarsha, K. B., \& Ismail, N. A. (2015). Blackboard Use by Faculty Members in the Colleges of Applied Sciences in the Sultanate of Oman. International Journal for Innovation Education and Research, 3(4). https://doi.org/10.31686/ijier.vol3.iss4.345

Alokluk, J. A. (2018). The Effectiveness of Blackboard System, Uses and Limitations in Information Management. Intelligent Information Management, 10(06). https://doi.org/10.4236/iim.2018.106012

Al Shammari, M. H. (2021). Devices and Platforms Used in Emergency Remote Learning and Teaching During Covid19: A Case of English Major Students in Saudi Arabia. Arab World English Journal, 1. https://doi.org/10.24093/awej/covid.6

Al-qahtani, M. S. (2019). The Relevance of Doing Virtual Classes: A Study of Postgraduate Female Students' Attitudes and Perceptions. Arab World English Journal, 1. https://doi.org/10.24093/awei/efl1.14

Al Zumor, A. W., K. Al Refaai, I., A. Bader Eddin, E., \& H. Aziz Al-Rahman, F. (2013). EFL Students' Perceptions of a Blended Learning Environment: Advantages, Limitations and Suggestions for Improvement. English Language Teaching, 6(10). https://doi.org/10.5539/elt.v6n10p95

Banditvilai, C. (2016). Enhancing Students' Language Skills through Blended Learning. Electronic Journal of e-Learning, 14(3), 220-229. https://eric.ed.gov/?id=EJ1107134

Brooks, D. C. (2015). ECAR study of faculty and information technology. Research report.

Louisville, CO: ECAR. Retrieved from http://www.educause.edu/ecar

Chen, J. C., Dobinson, T., \& Kent, S. (2020). Lecturers' perceptions and experiences of Blackboard Collaborate as a distance learning and teaching tool via Open Universities Australia (OUA). Open Learning: The Journal of Open, Distance and e-Learning, 35(3). https://doi.org/10.1080/02680513.2019.1688654

Choy, D., Xiao, J., \& lliff, J. (2005). How can technology help improve the quality of Blackboard faculty training and encourage faculty to use Blackboard? . Annual Proceedings-Orlando, 1, 1, 130-134. https://files.eric.ed.gov/fulltext/ED499958.pdf

Comas-Quinn, A. (2011). Learning to teach online or learning to become an online teacher: An exploration of teachers' experiences in a blended learning course. ReCALL Journal, 23(3), 218-232.

Corbin, J. M., \& Strauss, A. (1990). Grounded theory research: Procedures, canons, and evaluative criteria. Qualitative sociology, 13(1), 3-21.

Corbin, J., \& Strauss, A. (2015). Basics of qualitative research: Techniques and procedures for developing grounded theory (4th ed.). Thousand Oaks, CA: Sage.

Creswell, J. W. (2012). Educational research: Planning, conducting, and evaluating quantitative and qualitative research (4th ed.). Pearson. 
Proceedings of INTCESS 2022- 9th International Conference on Education \& Education of Social Sciences 17-18 January 2022- Online Conference

Desk, W. (2020). Coronavirus outbreak: Saudi Arabia closes schools and universities. https://www.geo.tv/latest/276467-coronavirus-outbreak-saudi-arabia-closes-schools-and-universities

D'Silva, R., \& Reeder, K. (2005). Factors that influence faculty members' uptake and continued use of course management systems. British Journal of Educational Technology, 36(6). https://doi.org/10.1111/j.1467-8535.2005.00578.x

Elsamanoudy, A., Al Fayz, F., \& Hassanien, M. (2020). Adapting blackboard-collaborate ultra as an interactive online learning tool during the COVID-19 pandemic. Journal of Microscopy and Ultrastructure, 8(4). https://doi.org/10.4103/JMAU.JMAU 2620

Ertmer, P. A., Gopalakrishnan, S., \& Ross, E. M. (2001). Technology-Using Teachers. Journal of Research on Computing in Education, 33(5), 1-26.

Flaxman, S., et al. (2020). Estimating the effects of non-pharmaceutical interventions on COVID-19 in Europe. Nature, 1-5. https://doi.org/10.1038/s41586-020-2405-7

Glaser, B. G. \& Strauss, A. L. (1967). The Discovery of Grounded Theory. Strategies for Qualitative Research. Chicago: Aldine.

Hamad, M. M. (2017). Pros \& Cons of Using Blackboard Collaborate for Blended Learning on Students Learning Outcomes. Higher Education Studies, 7(2). https://doi.org/10.5539/hes.v7n2p7

Hauck, M., \& Stickler, U. (2006). What does it take to teach online? CALICO Journal, 23(3), 463-475. Hodges, C., Moore, S., Lockee, B., Trust, T., \& Bond, A. (2020). The difference between emergency remote teaching and online learning. Educause Review. https://er.educ ause.edu/articles/2020/3/thedifference-between-emergency-remote-teaching-and-online-learning.

Ja'ashan, M. M. N. (2015). Perceptions and Attitudes towards Blended Learning for English Courses: A Case Study of Students at University of Bisha. English Language Teaching, 8(9). https://doi.org/10.5539/elt.v8n9p40

Ja'ashan, M. M. N. (2020). The Challenges and Prospects of Using E-learning among EFL Students in Bisha University. Arab World English Journal, 11(1). https://doi.org/10.24093/awej/vol11no1.11

Jackson, P. (1998). Focus Group Interviews as a methodology. Nurse Researcher. 6 (1), p72-84.

Khafaga, A. F. (2021). The perception of blackboard collaborate-based instruction by EFL majors/teachers amid COVID-19: A case study of Saudi universities. Dil ve Dilbilimi Çalışmaları Dergisi, 17(2). https://doi.org/10.17263/ills.904145

Lederman, D. (2020, March 18) Will shift to remote teaching be boon or bane for online learning? Inside Higher Education. https://www.insidehighered.com/digitallearning/

article/2020/03/18/most-teaching-going-remote-will-help-or-hurt-online-learning

McLafferty, I. (2004) Focus Group Interviews as a Data Collecting Strategy. Journal of Advanced Nursing, $48,187-194$

Mohsen, M. A., \& Shafeeq, C. P. (2014). EFL Teachers' Perceptions on Blackboard Applications. English Language Teaching, 7(11). https://doi.org/10.5539/elt.v7n11p108

Moosa, I. (2020). The effectiveness of social distancing in containing Covid-19. Applied Economics. https://doi.org/10.1080/00036846.2020.1789061

Murphy, M. P. A. 2020. "COVID-19 and Emergency eLearning: Consequences of the Securitization of Higher Education for Post-pandemic Pedagogy." Contemporary Security Policy 41 (3): 492-505. doi:10.1080/13523260.2020.1761749.

Nyabawa, R. f. (2016). Technology in Learning: Blackboard Usage \& Its Impact on Academic Performance; A Case for Universities in Lesotho. International Journal of Humanities and Management Sciences (IJHMS), 4(5), 455-461. http://www.isaet.org/images/extraimages/P1216204.pdf

O'Reilly, M. (2005a). Active noising: The use of noises in talk, the case of onomatopoeia, abstract sounds and the functions they serve in therapy. TEXT 25 (6), 745-761.

Pusuluri, S., Mahasneh, A., \& Alsayer, B. A. M. (2017). The Application of Blackboard in the English Courses at Al Jouf University: Perceptions of Students. Theory and Practice in Language Studies, 7(2). https://doi.org/10.17507/tpls.0702.03 
Proceedings of INTCESS 2022-9th International Conference on Education \& Education of Social Sciences 17-18 January 2022- Online Conference

Sewell, M. (2008). The use of qualitative interviews in evaluation. Tucson, AZ: The University of Arizona.

Sheerah, H. A. H. (2020). Using Blended Learning to Support the Teaching of English as a Foreign Language. Arab World English Journal, 6. https://doi.org/10.24093/awej/call6.13

Sobaih, A. E. E., Hasanein, A. M., \& Abu Elnasr, A. E. (2020). Responses to COVID-19 in Higher Education: Social Media Usage for Sustaining Formal Academic Communication in Developing Countries. Sustainability, 12(16). https://doi.org/10.3390/su12166520

Uziak J, Oladiran T, Lorencowicz E, \& Becker K. (2018). Students' and Instructor's Perspective on the use of Blackboard Platform for Delivering an Engineering Course. The Electronic Journal of E-Learning, 16(1), 1-15. https://www.researchgate.net/profile/Jacek-Uziak/research 